\section{Brewing Industry Research Foundation :} Dr. W. P. K. Findlay

Dr. W. P. K. Findeay has been appointed assistant director of the Brewing Industry Research Foundation, Nutfield, Surrey, in succession to Dr. A. H. Cook, who has recently been appointed director (see Nature, 181,810 ; 1958). Dr. Findlay graduated in botany at the Imperial College of Science and Technology, London, and afterwards gained an Empire Cotton Growing Corporation Fellowship for research at Cambridge and at the Imperial College of Tropical Agriculture, Trinidad. In 1927, he was appointed mycologist at the Forest Products Research Laboratory of the Department of Scientific and Industrial Research, where he now holds the post of senior principal scientific officer. Dr. Findlay has been president of the British Mycological Society, chairman of the Biological Council and president of the Association of Applied Biologists.

\section{Darwin-Wallace Centenary}

THE Royal Society, in conjunction with the Linnean and Geological Societies, is arranging a conversazione to be held on July 15 to mark the centenary of the reading before the Linnean Society of the paper "On the Tendency of Species to form Varieties", by Charles Darwin and Alfred Russel Wallace. A joint committee of the three Societies has chosen a number of exhibits, some of purely historical interest, others illustrating current research in fields in which Darwin and Wallace worked.

On the following day, July 16, the fifteenth International Zoological Congress opens in London under the presidency of Sir Gavin de Beer, director of the British Museum (Natural History). Sir Julian Huxley will deliver the Darwin-Wallace Memorial Lecture in the Royal Albert Hall during the inaugural meeting of the Congress of Zoology, at 11.30 a.m. on that day; this Lecture will be open to the public, and seats $(2 s .6 d$.$) are available at the Box Office of$ the Royal Albert Hall. The record number of nearly two thousand members from fifty-eight countries are attending the Congress, the main theme of which will this year be evolution. All the papers have been printed beforehand so that they can be distributed at the sessions where they are read, and they will be issued, together with records of the discussions, as the Proceedings of the Congress.

\section{Science in the Civil Service}

Is his chairman's address to the thirteenth annual delegate conference of the Institution of Professional Civil Servants at Hastings on May 19, Mr. E. Hewlett stressed the adverse effect on the structure of the whole of the professional scientific and technical Civil Service of the depression of status of higher grade professional and scientific staff which characterized the Service. Referring as example to the recent appointment of a Comptroller of the Patent Office from the administrative class without qualification in either science or law, Mr. Hewlett said that in 1925 a memorial was addressed to the Board of Trade which, after directing attention to the increasing importance of the Patent Office to our scientific industries, continued: "In modern industry, scientific invention exerts an overwhelming influence, inasmuch as only by invention can new industries be created and dying industries revived. We therefore ... direct your attention to the desirability of ensuring that the Comptroller of the Patent Office, in addition to possessing the requisite legal knowledge, should, by education and training, be familiar with scientific discovery and development as applicable to manufacture". This statement, said Mr. Hewlett, has even more force to-day, but although the battle had seemed to be won in 1925 when the Institution's journal commented that the fundamental principle that professional, scientific or technical work should be controlled by properly qualified officers was gaining wider acceptance, it seems that the success once achieved might be snatched or whittled away in a few years time.

A motion before the Conference, submitted by the Patent Office Examining Staffs Branch, viewed "with the utmost alarm the continuing encroachment into posts requiring professional qualifications and experience of officers qualified only in an administrative capacity" and registered "its full support of all actions of the National Executive Committee to arrest this practice". The general secretary, Mr. Stanley Mayne, in a wide-ranging speech on May 19, cited numerous other instances of Government failure to deal effectively with scientific matters, and to provide the conditions which would attract to the Civil Service sufficient men and women of the highest scientific and technical qualifications. Public service, said Mr. Mayne, itself is bound to be much of its own reward, but the treatment of some groups was so discouraging as to be a national danger.

\section{Agricultural Research}

REPLYING to an inquiry in the House of Commons on June 16 regarding progress in research into the prevention of losses among lambs from Nematodirus, the Minister of Agriculture, Fisheries and Food, Mr. J. Hare, representing the Lord President of the Council, said that much research bearing directly and indirectly on Nematodirus was in progress all over the world. Fundamental research on the lifehistory and epidemiology of the parasite was proceeding at several agricultural research institutes in Britain and work on new anthelmintics was being carried out by the pharmaceutical industry. It was too early to assess the bearing of this work in reducing losses from Nematodirus, but Mr. Hare agreed this was an important disease among hill sheep and said he would see that the scale of research devoted to it was adequate.

On June 16, and again on June 19, Mr. Hare was questioned about the work of the Farm Buildings Research Committee. This Committee, set up by the Agricultural Research Council in June 1957, had met three times. A special unit had been established by the Research Council to survey existing buildings and the immediate requirements of farmers. Reports had also been called for from experts in animal physiology, pest infestation and agricultural machinery. In collecting this information the Council was co-operating closely with the Agricultural Land Service, but Mr. Hare said that it would be some time before the results of these inquiries enabled the Committee to formulate research requirements and recommendations to meet them. Two members of the Committee were members of the Royal Institute of British Architects and consultation with the Institute would be arranged when it was likely to be of value.

\section{Aircraft Industry}

Replying to questions in the House of Commons on June 16, the Minister of Supply, Mr. Aubrey 